J. Asiat. Soc. Bangladesh, Sci. 44(1): 1-6, June 2018

\title{
NEWLY RECORDED FRESHWATER DIATIOMS (BACILLARIOPHYCEAE) FROM TWO WETLANDS OF DISTRICT SIRAJGANJ, BANGLADESH
}

\author{
KHURSHID NAHAR ${ }^{1}$ AND MONIRUZZAMAN KHONDKER ${ }^{* 2}$ \\ ${ }^{1}$ Department of Botany, Jagannath University, Dhaka, Bangladesh \\ ${ }^{2}$ Department of Botany, Dhaka University, Bangladesh
}

\begin{abstract}
A total 9 diatoms taxa newly reported from the sediments of Joysagar and Sitlai Beel has been reported. These are Navicula cuspidata var. heribaudii Peragallo, N. grimmei Krabke, Navicula americana Ehr, Pinnulara major (Kutz.) Cleve, P. braunii (Grun.) Cleve. P. brevicosta Cleve, P. divergens, P. acrosphaeria Brebisson, P. stauroptera (Grun.) Cleve and P. hemiptera (Kutz.) Cleve.
\end{abstract}

Key words: Epipelic diatoms, Wetlands, Northern Bangladesh, Joysagor, Sitlai Beel.

\section{Introduction}

Diatoms are good indicator of lake water pH (Batterbee et al. 1986). Since 1970's it has been apparent that diatom analysis of sediment cores for the purpose of re-constructing lake acidification relating to fallout of acidic pollutants from the atmosphere has considerable potential (Berge 1975, Davis and Berge 1980).

The ecology of epipelic diatoms are less well studied than their pelagic counterparts in various limnological studies in Bangladesh, except the work of Sultana et al. (2003). The seasonality and diversity of sediment diatoms and some of their taxonomic descriptions from two wetlands Joysagar and Sitlai Beel of Sirajganj, northern part of Bangladesh have been studied by Nahar and Khondker 2009 and Nahar et al. 2010. The present report on diatoms is a continuation of epipelons analysis of same areas i.e. Joysagar lake and Sitlai Beel.

\section{Materials and Methods}

The study sites Joysagar lake and Sitlai Beel are the part of Grameen Bank Fisherics Project, situated under Thana Rayganj and Tarash, repectively of Sirajganj district. Joysagar's geographical location is in between $24^{\circ} 28^{\prime} 40^{\prime \prime}$ and $24^{\circ} 28^{\prime} 50^{\prime \prime}$ E latitude and $89^{\circ} 25^{\prime} 24^{\prime \prime}$ and $89^{\circ} 25^{\prime} 42^{\prime \prime} \mathrm{N}$ longitude. On the other hand the geographical location of Sitlai Beel is $24^{\circ} 28^{\prime} 10^{\prime \prime}$ and E latitude and $89^{\circ} 26^{\prime} 30^{\prime \prime} \mathrm{N}$ longitude. The water area of

\footnotetext{
*Author for correspondence : E-mail: drknahar@hotmail.com
} 
Joysagar lake is $0.226 \mathrm{Km}^{2}$ having a length of $475.84 \mathrm{~m}$ and breadth $475.48 \mathrm{~m}$. The water area of Sitlai Beel is $0.04 \mathrm{~km}^{2}$ having a length of $243.84 \mathrm{~m}$ and breadth $170.68 \mathrm{~m}$. The taxonomy of diatom is based on the structure of ciliceous cell wall of frustules. In order to see the structure clearly the organic parts of the diatom must be removed. To prepare clean frustules diatoms collected from surface sediment of two lakes were treated by the wet combustion method (Van der Werff 1958). Mud sample weighing $1 \mathrm{~g}$ was taken in a Pyrex test tube. Thirty per cent of hydrogen per oxide and a few crystals of potassium dichromate was used to start cleaning of the frustules. After combustion was completed $30 \mathrm{ml}$ of distilled water was added to the suspension and kept at room temperature. Next day the water above the sediment was poured down. The suspension was rinsed in the same way for three times. After cleaning $0.2 \mathrm{ml}$ of well mixed diatom suspension was smeared on acid cleaned cover glass $(22 \times 22)$ and air dried. The cover glass was finally mounted on acid cleaned slide with hyrax, a mounting medium of high refractive index (Tolonen et al. 1986 and Charles 1986). Both the percentage frequency of the constituent taxa and the concentration of valves (Battarbee and Kneen 1982) were calculated. One slide from each sampling point of the two lakes was counted for each sample date (De Nicola 1986).

The permanent slides were made under oil immersion at a magnification of $1000 \mathrm{x}$ via Nikon Optiphot, UFX-11WA microscope fitted with a Nikon FX-35WA camera, Japan. All the images of diatom samples were transferred to digital files and plates of photomicrographs were prepared keeping the scale attached to them. The species were identified with the help of Germain (1981), Hustedt (1930), Wuthrick (1975), Tolonen et al. (1986).

\section{Results and Discussion}

The following nine fresh water diatoms were recorded from Joysagar lake and Sitlai Beel, in Sirajganj district, These species of Bacillariophyceae have been identified as new records for Bangladesh.

\section{Order: Naviculalis \\ Family: Naviculaceae}

\section{Navicula cuspidata Kutz. var. heribaudii Peragallo}

(PI. 1; Fig. 1)

(Germain 1981, 172, P1. 64, Fig. 3)

Cell length $65-110 \mu \mathrm{m}$, breadth $25.5 \mu \mathrm{m}$, striae 2 in $10 \mu \mathrm{m}$. Valve lanceolate with tappering ends. Axial area narrow with slightly broad central area. Striae punctate, thick, raphae central. 


\section{Navicula grimmei Krabke}

(Pl. 1; Fig. 2a-c)

(Germain 1981, 215. P1. 80. Figs 15 - 18, Hustedt 1930, 273. Fig. 448)

Cell length $6.5-11 \mathrm{~mm}$, breadth 3.5-3.8 $\mu \mathrm{m}$, striae 5-9 in $10 \mu \mathrm{m}$. Valve clliptical with captate ends, axial area linear, narrow, central area rounded, raphae straight, transapical striae radial, punetuate.

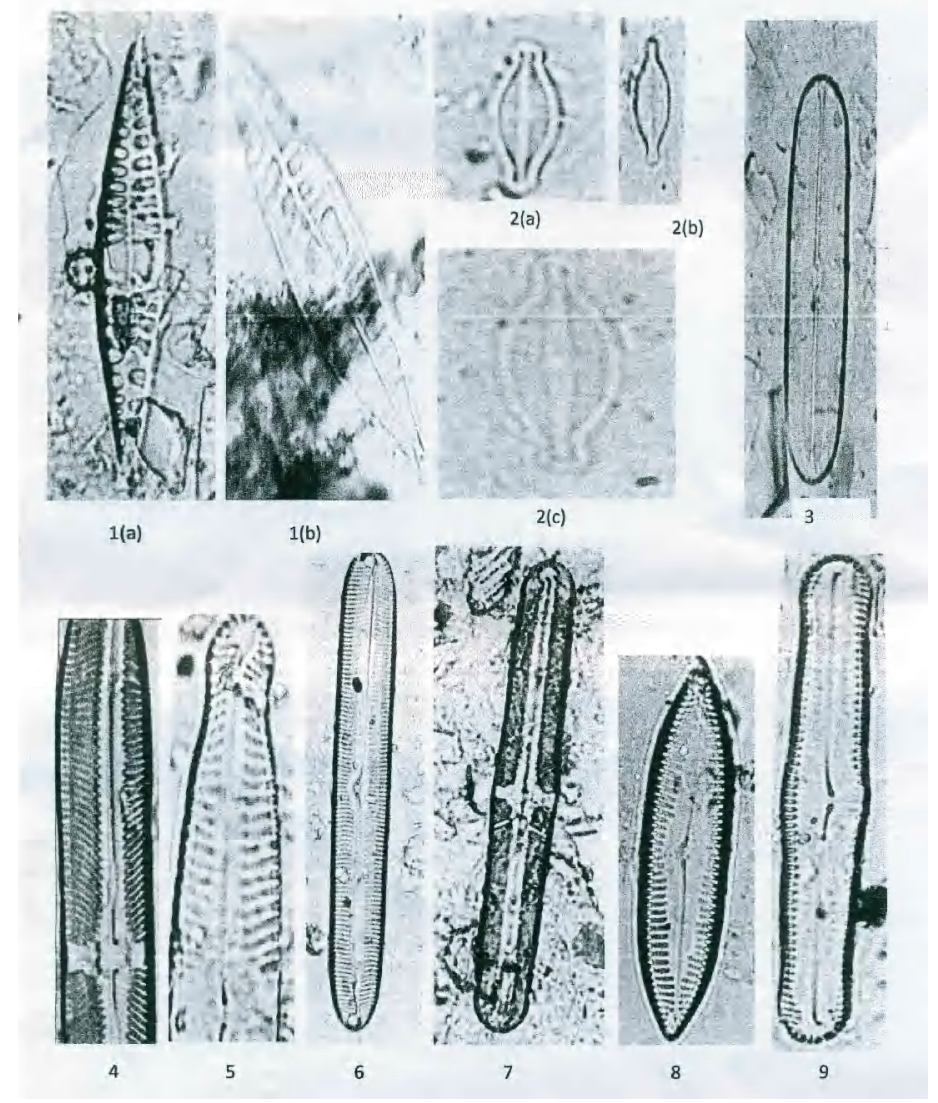

Plate 1. Fig : 1(a-b). Navicula cuspidata var. heribaudii, 2(a-c). Navicula grimmei, 3. Navicula americanas, 4. Pinnularia divergens, 5. Pinnularia braunii, 6. Pinnularia major, 7. Pinnularia brevicosta, 8. Pinnularia hemiptera. 9. Pinnularia stauroptera.

\section{Navicula americana Ehr.}

(Pl. 1; Fig. 3)

(Germain 1981, 205. P1. 77. Fig. 1, Hustedt 1930, 280. Fig. 464)

Cell length 68.4 - $147.2 \mu \mathrm{m}$, breadth 17.7 - $26.1 \mu \mathrm{m}$, striae 16 - 20 in $10 \mu \mathrm{m}$. Valve broadly linear with broadly rounded ends, axial area having narrow part with thin raphae 
and with lateral expansion, linear, raphae more or less straight with central and polar nodules oppositely curved and thicker, striae punctate, transapical, radiate.

\section{Genus: Pinnularia Ehrenberg}

\section{Pinnularia divergens $W$. Smith}

(PI. 1; Fig. 4)

(Germain 1981, 253, Pl. 89, Fig. 20, Pl. 90, Fig. 1-7)

Cell length $84 \mu \mathrm{m}$, breadth $12 \mu \mathrm{m}, 8$ striae in $10 \mu \mathrm{m}$. Valve linear with rounded ends. Axial area linear widening towards the central end to form a transverse fascia up to each margin.

\section{Pinnularia braunii (Grun.) Cleve}

(Pl. 1; Fig. 5)

(Germain 1981, 245, Pl. 88, Fig. 17; Hustedt 1930, 318, Fig. 578)

Cell length $40-100 \mu \mathrm{m}$, breadth $8.7-12 \mu \mathrm{m}, 7-10$ striae in $10 \mu \mathrm{m}$. Valve linear with attenuated cuneate apices, axial area linear widening towards the centre which forms a broad transverse fascia, central ends of the raphac turned to one side, striae radiate at central area, convergent towards the centre and divergent towards the tips.

\section{Pinnularia major (Kutz.) Cleve}

(Pl. 1; Fig. 6)

(Germain 1981, 259, Pl. 93, Fig. 3; Hustedt 1930, 333, Fig. 614; Nhyama 1971, 271, Pl. 5, Fig. 2)

Cell length 175.5 - $380.4 \mu \mathrm{m}, 25$ - 34 striae in $10 \mu \mathrm{m}$. Valve broadly linear with rounded ends, raphae complex with question marked terminal ends and central ends are turned to one side, axial area lincar with slightly tappering towards the ends and central area asymmetrically rounded, striae paralled crossed by a broad hand.

\section{Pinularia brevicosta Cleve}

(Pl. 1; Fig. 7)

(Hustedt 1930, 330, Fig. 609)

Cell lenght $80-120 \mu \mathrm{m}$, breadth $10-15 \mu \mathrm{m}$, striae $7-10$ in $10 \mu \mathrm{m}$. Valve linear, axial area linear, central area widening to form a fascia up to each margin. Raphe thread like, terminal ends question marked, turned to one side.

\section{Pinnularia hemiptera (Kutz.) Cleve}

(Pl. 1; Fig. 8)

(Hustedt 1930, 330, Fig. 608)

Cell length 41.7 - $50.7 \mu \mathrm{m}$, breadth 11.7 - $12.3 \mu \mathrm{m}$, striae 7 - 9 in $10 \mu \mathrm{m}$. Valve linear elliptical, outer line convex, axial area narrow, raphae thread like, both the central terminals curved to one side, transapical striae parallel. 


\section{Pinnularia stauroptera (Grun.) Cleve}

(Pl. 1; Fig. 9)

(Federovich 1980, 431, Fig. 3)

Cell length $30-133 \mu \mathrm{m}$, breadth $8-171.2 \mu \mathrm{m}$, striea 5 - 10 in $\mu \mathrm{m}$. Valve linear slightly widened at the centre with broadly rounded ends, axial area linear about three fourth of the breadth of the valve, raphae straght with rounded central nodules turned to one sides, terminal ends turned to the same sides, striae parallel, short.

\section{Acknowledgements}

The work is a part of Ph.D. thesis submitted by the first author (KN) who obtained a scholarship from the University Grants Commission (UGC) which is duly acknowledged. She is also indebted to the Director General, Secondary and Higher Education under the Ministry of Education, Government of People's Republic of Bangladesh, Dhaka for granting her study leave for carrying out the study.

\section{Reference}

Batterbee. R. W. and Kneen, M. J. 1982. The use of electronically counted microspheres in absolute diatom analysis. Limno. Oceanogr. 27: 184-188.

Batterbee, R. W., Smol, J.P. and Merilainen, J. 1986. Diatom as indicator of pH. In: Diatom and lake acidity". Smol, J.P., Batterbee, R.W., Davis, R.B and Merilainen, J. (eds). Dr. Junk Publ. Dordrecht. 5-14.

Berge, F. 1975. pH- forandinger og sedimentasjon av diatomeer Langtjern Norges Technish-Natur viten-skapelige Ifedskningirod Inter. Rapport 11. 1-18.

Charles, D.F. 1986. A new diatom species, Fragilaria acidobiontica, from acidic lake in north eastern North America. In: Diatoms and Lake Acidity (Smol, J.P., Batterbee, R.W., Davis, R.B and Merilainen, J. (eds)). Dr. W. Junk. Publ. Dordrecht. pp. 35-43)

Davis, R.B. and Berge, F.1980. Atmospheric deposition in Norway during the last 300 years as recorded in SNSF lake sediments 11, Diatom stratigraphy and inferred $\mathrm{pH}$. In Ecological Impact of Acid precipitation Drablos, D: and tollan, A (eds). Proc. Int, Conf, Ecol. Impact Acid Precp. SNSF project, Ose, Norway, 270-271.

De Nicola, D.M. 1986, The representation of living diatom communities in deep water sedimentary diatom assemblages in two (U.S.A.) lake. In. Diatom and lake acidity. Smol, J, P., Batterbee, R.W., Davis, R.B. and Merilainen, J. (eds). Dr. W. Junk Publ. Dordrecht. pp. 73-85.

Federovich S. L. 1980. Diatom Flora of Red Snow from Isbjorneo. Carey oer. Greenland. Nova Hedwigia. Band 33.. Braunchweig. J. Cramer. pp. 395-431.

Germain, H. 1981. Flora Des Diatomees. Diatomtphyceaes. Soc. Nouv. Des. Edin. Boubee. Paris. 444.

Hustedt, F. 1930. Die Susswasser-Flora Mitteleuropas. Heft. 10. Bacillariophyta (Diatomeae). Verlag Von GustavFischer, Jena. pp. 466.

Nahar, K. and Khondker, M. 2009. Addition to the list of freshwater diatoms (Bacillariophyceae) of Bangladesh. 1. Family: Coscinodiscaceae, Fragillariaceae and Eunoceaceae. Taxon Biodiv. Res. 9-12.

Nahar, K., Khondker, M. and Sultana, M. 2010. Seasonality and diversity of epipelic diatoms in two wetlands of Bangladesh. Bangladesh J. Bot. 39(1) 29-36. 
Nhyama, Y.N. 1971. Phytoplankton in lake Abasiri. Environ. Soc. Hokkaido. 5(2): 221-281.

Sultana, M., M. Khondker and Hoque. S. 2003. Status of epipelic algae and sediment composition of two urban ponds. J. Asiat. Soc. Bangladesh, Sci. 29(1): 37-44.

Tolonen, K. M., Harjula, L. R. and Patila, A.S. 1986. Acidification of small lake in Finland documented by sedimentary diatom and chrysophycean remans. In: Diatom and lake acidity. Smol. J. P., Davis, R. B and Merilainen, J. (eds), Dr. Junk Publ. Dordrecht. 171-199.

Ven der Werff. 1958. A new method of concentrating and cleaning diatoms and other organisms. Verhandl. In ter, verenin. Theoret Angewand. Limonol., Stuttgard. Germany, 12 : 276 - 277.

Wuthrick, M. 1975. Less Diatomee. DruckLie DinAir. Leistal. 300-333.

(Revised copy received on 5.11.2017) 